OPEN ACCESS

Edited by:

M. Brent Donnellan, Texas A\&M University, USA

Reviewed by:

Sebastian J. Lipina,

Unidad de Neurobiología Aplicada

(CEMIC-CONICET), Argentina

Josh Jackson

Washington University in St. Louis,

USA

${ }^{*}$ Correspondence:

Igor G. Menezes

gomesmenezesi@jbs.cam.ac.uk

Specialty section:

This article was submitted to Personality and Social Psychology, a section of the journal Frontiers in Psychology

Received: 15 December 2015

Accepted: 19 October 2016

Published: 23 November 2016

Citation:

Menezes IG, Duran VR, Mendonça Filho EJ, Veloso TJ, Sarmento SMS,

Paget CL and Ruggeri K (2016) Policy Implications of Achievement Testing Using Multilevel Models: The Case of Brazilian Elementary Schools.

Front. Psychol. 7:1727.

doi: 10.3389/fpsyg.2016.01727

\section{Policy Implications of Achievement Testing Using Multilevel Models: The Case of Brazilian Elementary Schools}

\author{
Igor G. Menezes ${ }^{1,2 *}$, Victor R. Duran ${ }^{1}$, Euclides J. Mendonça Filho ${ }^{1}$, Tainã J. Veloso ${ }^{1}$, \\ Stella M. S. Sarmento ${ }^{1}$, Christine L. Paget ${ }^{3}$ and Kai Ruggeri ${ }^{4}$ \\ ${ }^{1}$ Laboratory of Quantitative, Methods for Predictive Psychometrics, Psychology Institute, Federal University of Bahia, \\ Salvador, Brazil, ${ }^{2}$ Judge Business School, University of Cambridge, Cambridge, UK, ${ }^{3}$ Department of Education, University of \\ Oxford, Oxford, UK, ${ }^{4}$ Policy Research Group, Department of Psychology, University of Cambridge, Cambridge, UK
}

Large-scale educational assessment has been established as source of descriptive, evaluative and interpretative information that influence educational policies worldwide throughout the last third of the twentieth century. In the 1990s the Brazilian Ministry of Education developed the National Basic Education Assessment System (SAEB) that regularly measures management, resource and contextual school features and academic achievement in public and private institutions. In 2005, after significant piloting and review of the SAEB, a new sampling strategy was taken and Prova Brasil became the new instrument used by the Ministry to assess skills in Portuguese (reading comprehension) and Mathematics (problem solving), as well as collecting contextual information concerning the school, principal, teacher, and the students. This study aims to identify which variables are predictors of academic achievement of fifth grade students on Prova Brasil. Across a large sample of students, multilevel models tested a large number of variables relevant to student achievement. This approach uncovered critical variables not commonly seen as significant in light of other achievement determinants, including student habits, teacher ethnicity, and school technological resources. As such, this approach demonstrates the value of MLM to appropriately nuanced educational policies that reflect critical influences on student achievement. Its implications for wider application for psychology studies that may have relevant impacts for policy are also discussed.

\footnotetext{
Keywords: large-scale educational assessment, school achievement, hierarchical linear modeling, education policies, Brazilian education system
}

\section{INTRODUCTION}

In Latin America, most educational assessment systems were established during the 1990s, either as an unfolding of accumulated experience in assessments for specific purposes or as part of education reform programs that were common in that decade. Those national systems vary largely in terms of their institutional framework; technical, financial, and operational provisions, as well as the social, economic, and political ambiance in which they operate. Economic fluctuations and political instability affect national educational assessment systems differently, and it has been recognized that those systems supported by institutions that are independent of education ministries-and thus enjoy greater technical and management autonomy-tend to be more stable (Ferrer, 2006). 
That is the case of Brazil's National Institute of Educational Studies and Research (Instituto Nacional de Estudos e Pesquisas Educacionais Anísio Teixeira-INEP).

Created in the late 1930s as a research and consulting agency to support the Brazilian educational system, INEP began to play a strategic role in the 1990s, as the education reform established systematic, comprehensive, large-scale educational assessments with increasingly important effects over educational policies in the following decades. It's relative independence and accumulated experience warranted INEP to consolidate and refine techniques that now directly influence all agents involved in the teaching-learning process that takes place within the scope of the national education system: government, schools, teachers, parents, and students.

After 21 years of military government, the process known in Brazil as "re-democratization" entailed a comprehensive reform of the state, initiated by the review and enactment of a new Federal Constitution in 1988. The state reform was first operationalized in the health sector, with the establishment of a universal, integral and decentralized Unified Health System (SUS) by national law in 1990. In the same year the National System for Educational Assessment (Sistema de Avaliação da Educação Básica-SAEB) was first administered by INEP to a sample of public schools in 25 Brazilian states to produce indepth understandings regarding the outcomes of teaching and learning processes in the national education system (Ministério da Educação, 2001).

Under the National Educational Bases and Guidelines Law (Lei de Diretrizes e Bases da Educação-LDB) in 1996, SAEB gained a strategic role in guiding policies aimed at enhancing the quality of education in Brazil. Following provisions of the new Constitution, LDB established not only a universal and decentralized educational system, but was also required to develop a National Plan for Education that would set forth guidelines, goals and strategies for educational policy every 10 years (Castro, 1998; Dourado, 2002; Castro and Menezes, 2003).

SAEB underwent important transformations in each subsequent edition $(1997,2001,2003)$, comprising technical improvements (e.g., creation of Test Specifications, since there was no National Curriculum in Brazil at that time) and broadening of the scope of information collected to cover more academic subjects and aspects of school and family context. In 2005, SAEB went on to encompass two major assessments: the National Basic Education Assessment (Avaliação Nacional da Educação Básica-ANEB), that addressed management aspects and was sample based, and the National Student Achievement Assessment (Avaliação Nacional do Rendimento EscolarANRESC) or Prova Brasil. Prova Brasil benefited from successive improvements to its SAEB predecessor and, by being census and not sample based, allowed the creation of achievement indicators for individual schools, municipalities, cities, states, and Brazil as a whole. Therefore, Prova Brasil introduced accountability into Brazil's educational scenario.

Prova Brasil measures skills in Portuguese-with focus on reading comprehension-and Mathematics-with focus on problem solving. Students also complete a questionnaire designed to collect sociodemographic and family information, as well as school records and habits (studying habits, culture seeking, and so forth). Teachers and school principals participate in data collection by completing questionnaires regarding school infrastructure and working conditions, as well as personal and professional background information.

With Prova Brasil, national, regional, and local statistics are now being generated, which allow direct comparisons that provide the government with relevant information that could be used for the development and monitoring of educational public policies. The Basic Education Development Index (Índice de Desenvolvimento da Educação Básica-IDEB), launched in 2007, introduced a sophisticated informational tool to guide political action by combining proficiency indicators from Prova Brasil with information about students (approval) into a single scale that ranges from 0 to 10 . IDEB facilitated the monitoring of schools with low student achievement and, as an accountability device, was used as criterion for providing technical and financial resources based on these schools' development plans (Napier, 2014).

One of the goals of the National Education Plan (Plano Nacional de Educação-PNE) for 2011-2020 was for the IDEB to reach a national score of 6 by 2021, which would place Brazil at the same level of current academic achievement of developed countries that are members of the Organization for Economic Cooperation and Development-OECD. The current national public system IDEB score, calculated in 2013, was 4.9 in the early years of elementary school ( 0.2 above what was projected) and 4.0 in the final years (0.1 under projection, Ministério da Educação, 2015).

Brazil's public educational expenditure rose from $3.5 \%$ of GDP in 2000 to $6.1 \%$ in 2011 , which represented the highest growth of investment in education of any OECD and G20 partner countries (OECD, 2014a). In the elementary education system, most of this investment is directed toward the enhancement of educational through additional resources to schools, especially technology, infrastructure, and teacher training. For Brazil to achieve these development goals, policies must be developed with greater precision, a task that requires a substantial understanding of the interactions, potential, and limitations of a variety of factors in a multilevel structure. Educational effectiveness studies are made complex by the mesh of micro factors that interact at each level of education (Cervini, 2002) however, the search the most important variables at each level must continue as must their role in the development of educational policies (Cervini, 2006).

\section{MATERIALS AND METHODS}

\section{Participants}

The total number of participants for Mathematics was 7726 schools, 11,421 classes and 127,256 students, and for Portuguese was 7688 schools, 11,361 classes, and 126,527 students. With regard to the total amount of observations after listwise deletion, most of the sample was composed by females $(M=51.4 \%, P=$ $51.4 \%)$. Students were mainly from public schools $(M=81.2 \%$, $P=81.2 \%)$, and the 10 -year-old group was the most frequent $(M=54.3 \%, P=54.2 \%)$. The majority of students were from 
the Southeast $(M=60.4 \%, P=60.6 \%)$, followed by the South $(M=15.6 \%, P=15.2 \%)$, Northeast $(M=14.5 \%, P=14.5 \%)$, North $(M=5.5 \%, P=5.5 \%)$, and Midwest $(M=4.1 \%$, $P=4.3 \%)$ regions. Although the relative frequencies for the sample differ from that ones observed for the population, the rank order remains the same, i.e., in the population, the Southeast was the region with more students answering Prova Brasil, the same occurring in the sample. The same pattern was repeated for all regions.

\section{Instruments}

\section{Variable Selection}

According to Ferrão (2003), variables associated with both internal and external factors affecting school must be taken into account when assessing achievement. Thus, based on the literature and previous studies conducted in Brazil that investigated the relationships between academic achievement and student sociodemographic variables, this research selected a set of 22 relevant variables to control for their effects. To achieve a better understanding of the variables investigated in this study, they are explored here at each of their levels. The variables for the first level (students) are: sociodemographic characteristics, cultural and social capital, motivation and self-esteem, studying habits and school records (Albernaz et al., 2002; Jesus and Laros, 2004; Menezes-Filho, 2007; Brasil, Ministério da Educação, 2008; Riani and Rios-Neto, 2008; Castro, 2009; Couri, 2010). For the second level (classes), the following teacher variables were selected: sociodemographic characteristics, level of education and expectations, professional experience, pedagogical practices, and working conditions (Mello, 1994; Ferrão and Fernandes, 2001; Albernaz et al., 2002; Soares and Alves, 2003; Menezes-Filho, 2007; Riani and Rios-Neto, 2008; Castro, 2009; Felicio, 2010; Palermo, 2011). Finally, the third level (school characteristics) was comprised of the sociodemographic characteristics of the principals, level of education and expectations, professional experience, leadership, working conditions of staff, collaborative work, academic and disciplinary practices, pedagogical resources and school facilities and equipment (Jesus and Laros, 2004; Soares, 2004, 2007; Andrade and Laros, 2007; Biondi and Freitas, 2007; Menezes-Filho, 2007; Riani and Rios-Neto, 2008; Castro, 2009; Castelar et al., 2012; Passador et al., 2012; Lamas et al., 2013).

The variable selection procedure was carried out based on a theoretical framework study conducted by Franco et al. (2003). This work was based on previous systematic reviews and made relevant contributions to the theoretical and empirical field of educational assessment in Brazil. SAEB survey questionnaires were developed in conformity with this seminal research, which ultimately guided the variable selection for Prova Brasil questionnaires. Constructs and variables for each level can be shown in Table 1.

This study aims to identify how much of the variance in academic achievement of fifth grade students on Prova Brasil is explained by each one of the three levels (students, classes, and schools), and which of the aforementioned variables are the best predictors of academic achievement.
The variables presented in this study are those deemed statistically significant for both Mathematics and Portuguese. Also, these variables are the ones that have the largest chi-square, corroborating the decision above.

This study used data from five different instruments. Four questionnaires are designed to assess sociodemographic characteristics of schools, teachers, and students. The fifth measure is Prova Brasil itself. The students' questionnaire has 54 items concerning sociodemographic background characteristics and also the engagement of students and their parents in education-related activities. This questionnaire is completed by students right after Prova Brasil has been administered. The teachers' questionnaire is comprised of 119 items concerning their background, pedagogical practices, and their socioeconomic and cultural profile. It also contains items regarding the classes attending the exam, such as availability of essential academic resources. Each school is assessed by two separate instruments; the first has 72 items and focuses on the characteristics of the school. The second has 212 items and is also completed by the school principal, who reports data related to school infrastructure, resources and available materials, school safety and school conservation status, as well as the practices and attitudes of teachers and students. Lastly, Prova Brasil has two parts of 22 items each for Portuguese and Mathematics, based on specifications of the Brazilian National Education Curriculum. Prova Brasil scores are based on the SAEB proficiency scales, which split the achievement levels into different categories regarding distinct levels of cognitive ability. The Portuguese scale is comprised of nine categories, with scores ranging from 0 to 350 . The Mathematics scale is bit larger and is divided in 12 categories, ranging from 0 to 425 .

\section{Data Analysis Procedures Dataset Preparation}

This study utilizes secondary datasets obtained from the Brazilian Ministry of Education website (Brasil, Ministério da Educação, 2015). Every student, teacher, principal, and school has a unique identification number which permitted a merge of all of the datasets into two matrices, one containing achievement information for Portuguese and the other for Mathematics. Producing separate datasets is justified because different sociodemographic information is available for each area of knowledge, both for students and teachers. Additionally, the main goal during the merging process was to maximize the number of observations with complete data (i.e., without missing cases).

The rate of missing data for all instruments is high, which is aggravated by the hierarchical structure of the data. That is, missing information about a single school is propagated to sometimes hundreds of students that belong to that same school. We believe that the length of the questionnaires is a possible explanation for the high frequency of missing data. The voluntary, low-stakes nature of the Prova Brasil testing is also likely a factor in the large amount of missing data (see Sundre and Wise, 2003; Wise and DeMars, 2005, for example).

The first stage of the merging process joined all datasets into a single one without removing any observation, generating 
TABLE 1 | Levels and their selected variables for predicting academic achievement in Prova Brasil.

\begin{tabular}{|c|c|c|}
\hline Level & Group & Variables \\
\hline \multirow[t]{4}{*}{ First } & Socio demographic characteristics & Age, ethnicity, gender, parent education, socioeconomic status \\
\hline & Cultural and social capital & Culture seeking behaviors, study habits, reading habits, hours dedicated to household chores, child labor \\
\hline & Parents & Parents involvement \\
\hline & School records & School dropout, school failure \\
\hline \multirow[t]{4}{*}{ Second } & Sociodemographic characteristics of teachers & Teacher's ethnicity, gender \\
\hline & Teacher's level of education and expectations & Teacher's level of basic and supplementary education \\
\hline & Pedagogical practices & General pedagogic practices \\
\hline & Working conditions & Number of schools the teacher works, contract type, working hours per week \\
\hline \multirow[t]{3}{*}{ Third } & Staff working conditions & Actions to prevent violence, violence inside school \\
\hline & Academic and disciplinary practices & Presence of school dropout program, supporting program for students \\
\hline & School facilities and equipment & Information and communications technology, public areas \\
\hline
\end{tabular}

entire rows of missing data from unmatched information across the datasets. The second step was to remove all variables not to be considered in the hierarchical model. Finally, all observations with missing values were excluded using listwise deletion, reducing the amount of observations from an initial 5.2 million to 127,256 and 126,527 observations for Mathematics and Portuguese, respectively. These procedures aimed not only to minimize lost information but also to preserve group structure, which is essential to perform Multilevel Modeling adequately. Although, it is acknowledged that this listwise deletion strategy has limitations (Little and Rubin, 2002), such as massive losses of data that could increase the probability of Type II errors (King et al., 2001), Allison (2002) states that listwise deletion will produce unbiased estimates even if the data are not missing at random. Furthermore, the author points out that listwise deletion might reasonably be preferred over maximum likelihood or multiple imputation if a large amount of data remains after the deletion procedure.

In order to compare for differences in the distributions of the population and the sample designed for this study, density functions were calculated and plotted. In general, no major disparities were observed, as can be seen in Figure 1.

\section{Multilevel Modeling}

When investigating critical factors-whether common or those less regularly considered-there are considerable challenges to appropriately analyse the available data. This requires a hierarchical approach, which takes into account potential conflicts in variation within and between classrooms and schools. As such, it is argued that the multilevel model approach is best suited to address these in a robust and appropriately nuanced way, considering the many potential levels of impact relevant to effective educational policy. MLM is a generalization of linear regression models particularly suited for hierarchically structured data, wherein information is repeated for multiple observations that belong to the same group. With improvements in computer performance observed in the late 1980s, Multilevel Modeling (MLM) started to be widely used in education as a technique for the prediction of academic achievement. Three hierarchies, also known as levels, were defined for Prova Brasil: students, classes and schools. The information available for a given school is repeated across all students of that school, which is ideally modeled by a MLM. This phenomenon contributes to increasing collinearity among covariates in the data, which, in standard regression settings, produce biased estimates. The chosen MLM resolves this issue by estimating a separate intercept for each group in higher leveled covariates, which, in turn, reduces the bias in the slope terms (Gelman and Hill, 2007).

Academic achievement measures the extent to which students perform in different academic subjects. For this study, it is set as the dependent variable, and the variables investigated at the three levels of the MLM are the independent ones. Two types of models were tested in this research. The first one was a null model, which does not consider the independent variables at any of its levels and therefore does not explain any variance in the dependent variable; it only estimates the partitioning variance of the dependent variable due to each of the levels considered. The second was a conditional model, which is drawn from the null model, with the independent variables for each level being added in order to explain part of the total variability.

For both null and conditional models, only random intercepts were considered in this study. In effect, for a three-level null model with random intercepts, the student's achievement $\left(Y_{i j k}\right)$ is predicted from the sum of the average of their class $\left(\beta_{0 j k}\right)$ with the error $\left(e_{i j k}\right)$, which represents the distance between their score and the average of their class. In addition, the student's class average will be predicted at Level 2, from the student's school average $\left(\gamma_{00 k}\right)$ plus a random effect $\left(u_{0 j k}\right)$. Finally, the student's school average will be predicted at the Level 3, from the student's school overall average $\left(\pi_{000}\right)$ plus a random effect $\left(r_{00 k}\right)$. All random effects are assumed to be normally distributed, with mean equals zero, and variance $\sigma^{2}$. The three-level null model with random intercept is shown in Equation (1).

$$
\begin{array}{r}
Y_{i j k}=\beta_{0 j k}+e_{i j k} \\
\beta_{0 j k}=\gamma_{00 k}+u_{0 j k} \\
\gamma_{00 k}=\pi_{000}+r_{00 k}
\end{array}
$$

Where, 


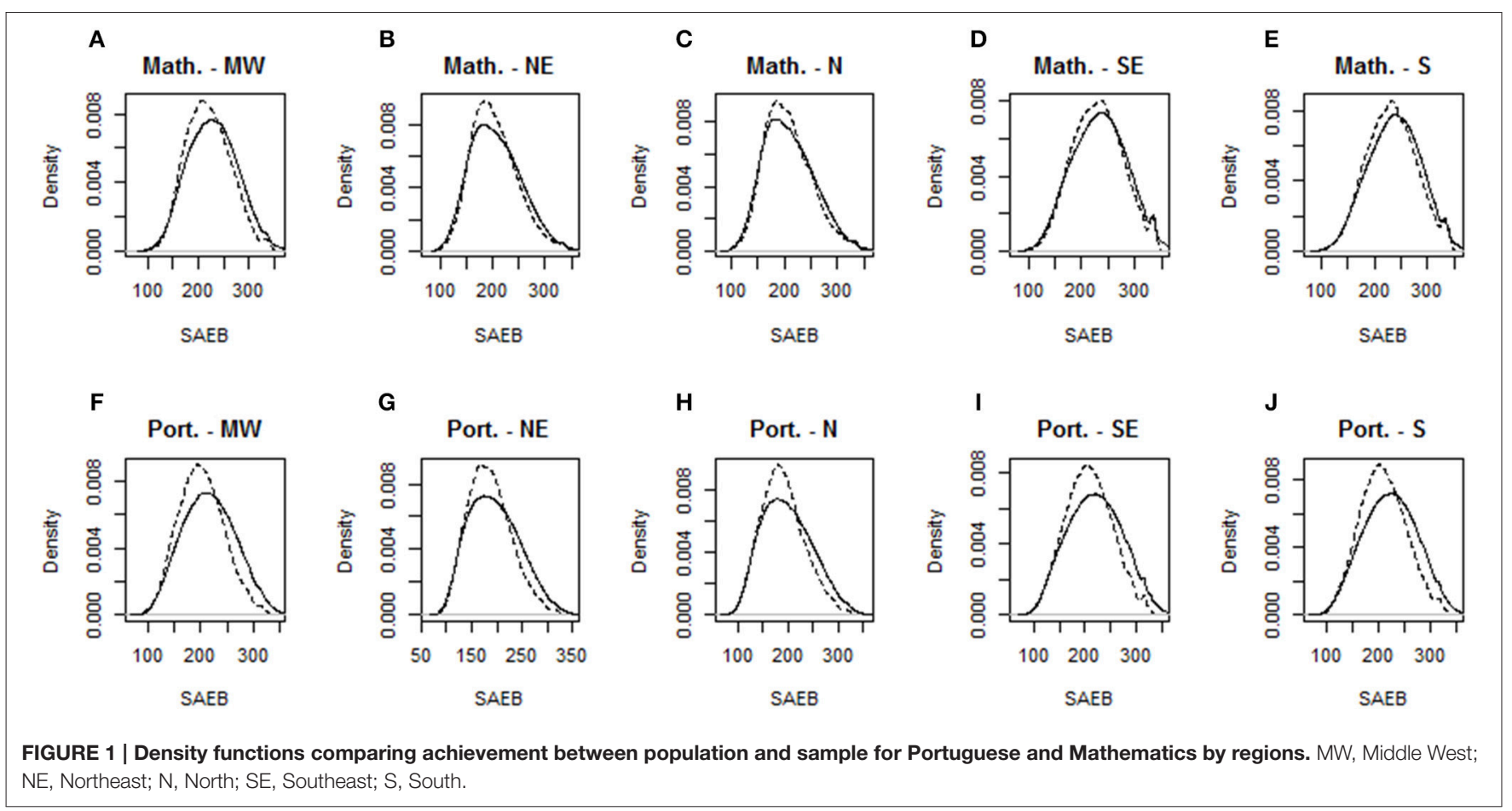

$i=1,2,3, \ldots, i$ students in the $j^{t h}$ class of the $k^{\text {th }}$ school

$Y_{i j k}$ : academic achievement of the student $i$ studying in the class $j$ of the $k$ school

$\beta_{0 j k}$ : academic achievement mean score for the class $j$ of the school $k$

$e_{i j k}$ : random error of the $i^{\text {th }}$ student in the $j^{\text {th }}$ class of the $k^{\text {th }}$ school

$\gamma_{00 k}$ : academic achievement mean score in school $k$

$u_{0 j k}$ : random error of the $j^{\text {th }}$ class for the $k^{\text {th }}$ school

$\pi_{000}$ : overall average, considering the total of students

$r_{00 k}$ : random error of the $k^{\text {th }}$ school

In order to identify predictive sociodemographic variables for academic achievement in Prova Brasil, this study utilized two types of MLM models: a null and a conditional model, as defined at the introduction.

The procedures for fitting the multilevel model were as follows:

i. To estimate a Null-Model for the two two-level modelsstudents and classes, and students and schools-, and for the three-level model in order to check the variance partitioning among the levels for each model;

ii. To compare the goodness-of-fit between each null-model and select the model that best fits the data and explains the most variability found at the student level. Three indices were calculated for that: (a) The log-likelihood ratio, which tests the hypothesis that the variance in achievement between subjects on the same level is zero. Also, it assumes the existence of effects of higher levels within the individual level. Log-likelihood statistic is calculated using an adaptive Gauss-Hermite approximation; (b) The Akaike's Information Criterion (AIC), which compares the models being tested to a hypothesized true distribution. The lower the AIC value, the better the model; and (c) BIC, Bayesian Information Criterion, which can be interpreted in the same fashion as the AIC, but the fitted models are based on the posterior probability distribution. The more probable the model, the more defensible it is;

iii. To investigate whether the residuals follow a normal distribution. Moreover, both class and school effects must also be significantly different from zero;

iv. To estimate three different random intercept conditional models considering the selected variables for each level using the Restricted Maximum Likelihood method;

v. To calculate the three statistics introduced at the second step for each conditional model in order to compare the deviance between the models. Again, the smaller the model deviance in comparison to others, the better its fit;

vi. For each variable to be considered in each conditional model, the following statistics are produced: Chi-square, the regression Beta, and a $\mathrm{t}$ estimate. The Chi-square is interpreted as a deviation of group means from the grand mean and it gives the test statistic for each variable in the model. The Betas have the same interpretation as in standard regression, the average increase in the dependent variable given a one point increase in the predictor. The $t$ statistic is used to obtain a $p$-value which assess the significance of the variable to the model as a whole.

\section{RESULTS AND DISCUSSION \\ Descriptive Statistics}

Mean scores for Portuguese Language and Mathematics are presented in Table 2. 
TABLE 2 | Mean and standard deviation scores at Prova Brasil 2011-Portuguese and Mathematics (SAEB scale).

\begin{tabular}{lcccccc}
\hline \multirow{2}{*}{ Dataset } & \multicolumn{6}{c}{ Mean SAEB scores } \\
\cline { 2 - 7 } & $\mathbf{M W}$ & $\mathbf{N E}$ & $\mathbf{N}$ & $\mathbf{S E}$ & $\mathbf{S}$ & General \\
& $\boldsymbol{M}(\boldsymbol{S D})$ & $\boldsymbol{M}(\boldsymbol{S D})$ & $\boldsymbol{M}(\boldsymbol{S D})$ & $\boldsymbol{M}(\boldsymbol{S} \boldsymbol{D})$ & $\boldsymbol{M}(\boldsymbol{S D})$ & $\boldsymbol{M}(\boldsymbol{S D})$ \\
\hline Population & 228.53 & 206.08 & 208.72 & 234.10 & 238.45 & 224.52 \\
Math. & $(48.27)$ & $(48.16)$ & $(47.55)$ & $(50.77)$ & $(48.67)$ & $(51.12)$ \\
Population & 216.31 & 195.01 & 198.32 & 219.92 & 222.77 & 211.45 \\
Port. & $(50.39)$ & $(50.33)$ & $(50.08)$ & $(53.10)$ & $(50.70)$ & $(52.90)$ \\
Sample & 219.50 & 202.45 & 206.02 & 230.32 & 232.57 & 224.85 \\
Math. & $(42.98)$ & $(43.31)$ & $(43.75)$ & $(46.60)$ & $(45.63)$ & $(46.99)$ \\
Sample & 201.12 & 185.48 & 189.01 & 207.70 & 208.71 & 203.33 \\
Port. & $(42.72)$ & $(42.80)$ & $(42.53)$ & $(45.39)$ & $(43.66)$ & $(45.31)$ \\
\hline
\end{tabular}

MW, Midwest. NE, Northeast; N, North; SE, South East; S, South.

\section{Model Selection}

The first stage of the model selection procedure consisted of assessing the influence of higher levels on individual scores based on statistics of likelihood ratio and explained variance. This analysis guided the decision concerning which levels would be included in the MLM. A total of three models were tested, with all combinations of models containing two and three levels.

Although, the variability of academic achievement accounted for by the 2 two-level models tested are similar $\left(\sigma_{\text {classes }}^{2} M=\right.$ $24.77 \%$ and $\sigma_{\text {classes }}^{2} P=18.62 \%$ for classes and $\sigma_{\text {schools }}^{2} M=$ $23.65 \%$ and $\sigma_{\text {schools }}^{2} P=17.25 \%$ for schools), in the threelevel model the variance is proportionally higher for schools than for classes $\left(\sigma_{\text {classes }}^{2} M=6.33 \%\right.$ and $\sigma_{\text {classes }}^{2} P=5.97 \%$ for classes and $\sigma_{\text {schools }}^{2} M=18.89 \%$ and $\left.\sigma_{\text {schools }}^{2} P=12.86 \%\right)$. This suggests that the variance proportion due to differences between schools should be taken into consideration in multilevel modeling and the three-level model will therefore be more likely to better explain academic achievement. In spite of that, a loglikelihood ratio for each null-model was calculated so as to verify what model contains less deviance. The log-likelihood is calculated using an adaptive Gauss-Hermite approximation. The test assesses the existence of effects of higher levels within the individual level.

Both class and school effects were significantly different from zero, with a $95 \%$ confidence interval estimated from the residuals estimated at levels two and three respectively. The ML deviance for the two-level model (students and schools) for Mathematics was 1322197 (AIC: 1322203; BIC: 1322233), whereas the ML deviance for the three-level model (students, classes and schools-Mathematics) was 1321171 [AIC: 1321179; BIC: $1321218 ; p<0.001 ; \Delta \mathrm{X}_{(1)}^{2}=1026.8$ ], showing therefore a better fit for this model. Likewise, the ML deviance for the two-level model for Portuguese was 1312406 (AIC: 1312412; BIC: 1312442), whereas the ML deviance for the three-level model was 1311610 [AIC: 1311618 ; BIC: $1311657 ; p<0.001 ; \Delta \mathrm{X}_{(1)}^{2}=$ 796.51], showing then a better fit.

The chosen model for both disciplines included higher levels for class and school. The results of the likelihood ratio tests were significant, which suggests that the three-level model is significantly different from the others, justifying the increase in complexity. However, as with all tests of the chi-squared family, large sample sizes produce tests that are too powerful, which increases the chances of type I errors. The specificities of the chosen conditional model are described below.

\section{Three-Level Model}

Once the multilevel model that best explains academic achievement was fitted, a set of variables from each of the three levels was chosen based on the significance of their chisquare, slope of the regression line (Beta), associated t-statistic and respective $p$-values. Table 3 shows the estimates calculated for each variable deemed important to represent its respective level ordered by their chi-square in Portuguese. For Portuguese, 15 variables were selected to represent the first level (student), 11 variables to the second level (teacher/classes), and 11 variables to the third level (schools). For Mathematics, 15 variables were selected to represent the first level (student), 11 variables to the second level (classes), and 10 variables to the third level (schools). Analyses of the results in light of the Brazilian education policies addressing the topics are provided for variables with highest statistical significance and beta, separated by level.

\section{First Level}

The variables that most strongly predicted change in scores of Prova Brasil were the same for Portuguese and Mathematics at the first (student) level, as displayed on Table 3.

Variables associated with greater increase in scores for both tests were, in order of magnitude: study habits, student's age, mother, and father education and gender. Parent involvement, reading habits and socioeconomic status (SES) were also associated with significant positive variation in Portuguese and Math scores.

Variables most significantly associated with decrease in Portuguese and Math achievement as measured by Prova Brasil were school failure, amount of time dedicated to household chores, child labor, ethnicity, school dropout, and culture seeking behaviors.

In this study, study habits corresponded to the frequency with which students did homework. Always or frequently doing homework was the variable that most positively impacted both Portuguese and Math achievement, followed closely by student's age, which is an age-within-grade indicator.

Evidence on the impact of homework on school achievement has been accumulated for almost a century. Although, there is consensus on the positive impact of homework, many factors must be considered, such as educational level, academic subject, time spent on homework, to what extent the teachers correct, feedback, and fit homework to content explored in class (Núñez et al., 2015). Many studies show that impact of homework on achievement varies between educational levels, being neutral or negative in some grades of Elementary Education and more positive in High School (Cooper et al., 2006). Murillo and Martinez-Garrido (2014) found that assigning homework is a common practice in Latin America, although correcting homework or using it in teaching sessions is not so frequent, especially in Brazil, when compared to 15 other latin american 
TABLE 3 | Standardized coefficients, chi-square, and significance levels of the first level variables.

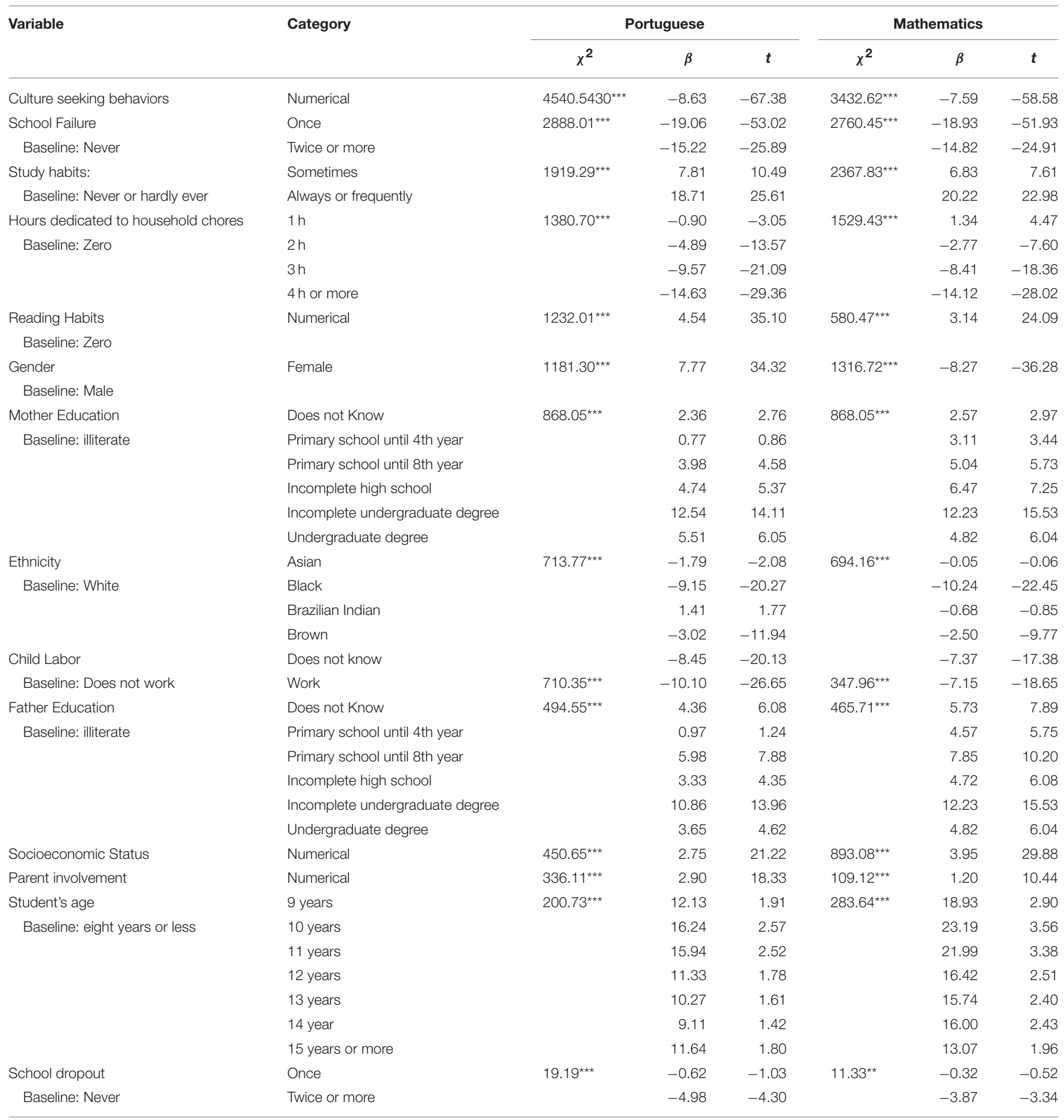

Significance levels: ${ }^{* * *} p<0.001 ;{ }^{* *} p<0.01 ;{ }^{*} p<0.05$.

countries. In our study, doing homework frequently exerted a positive impact over Brazilian 5th graders' Math and Portuguese achievement, regardless of whether or not it was supported by efficient use in classroom.

Being 10 and 11 years old-thus having the expected age for 5th grade in Brazil (Ministério da Educação, 2009)—predicted a large amount of positive variation over both Math and Portuguese scores. Being 9 years old (expected age at the beginning of 4rth grade) was the third greatest variation on Portuguese and Math achievement as accounted for by student's age, which tended to decrease between 12 and 14 years. Research on the relation between age and achievement show that years 
of schooling may exert a greater influence over academic achievement than years of age (Cliffordson and Gustafsson, 2010). Martin et al. (2011) advert that age-within-grade variation is largely influenced by national educational policies regarding age of entry to school and promotion/retention. The authors indicate that countries that are more flexible regarding age of school entry and that use retention practices are those with greater age variation within a certain grade, as our shown by our results. By analyzing data of 4 th graders on the PIRLS 2006 countries (that would correspond to 5th graders in Brazil), Martin et al. (2011) found that in those countries with strict age cutoffs for entering school and policies of automatic promotion, older students showed higher average reading achievement when compared to the younger students. Nevertheless, PIRLS 2006 countries with a lesser degree of economic development tended to have the oldest students at 4 th grade and the lowest average reading achievement.

Higher mother and father education, parent involvement and higher family socioeconomic status (SES) had positive effects, consistent with many other studies such as Hattie's (2009) meta-analysis of 800 other meta analyses related to school achievement in English speaking, highly developed countries. The author found that family SES, parental education (what can be considered part of SES indicator) and parental involvement have medium to large effect sizes over student achievement $(0.57,0.60$, and 0.51 respectively). Many studies also show to what extent ethnicity and father's occupation are significant contributors to student achievement (Peng and Hall, 1995; McCoy, 2005). Parental education and family SES level show positive correlations with the student's quality of achievement (Parelius and Parelius, 1987; Caldas and Bankston, 1997; Ma and Klinger, 2000; Mitchell and Collom, 2001; Jeynes, 2002). Students with high level of SES perform better than middle class students and middle class students perform better than students with low level of SES (Garzon, 2006; Kahlenberg, 2006; Kirkup, 2008). The effect of a student's SES on their academic achievement is widely accepted in both international educational literature (Gray et al., 1990; Mortimore, 1991; Goldstein et al., 1993; Sammons, 1995) and Brazilian literature (Hasenbalg and Valle Silva, 1990; Harbison and Hanushek, 1992; Souza and Valle Silva, 1994; Arias et al., 2004; Fernandes, 2004).

Student's gender had significant impact for both Portuguese and Mathematics. Results showed that female 5th graders performed better in Portuguese and worse in Mathematics. The relationship between gender and academic achievement has been discussed for decades (Eitle, 2005). A gap between the achievement of boys and girls has been found, with girls showing better achievement than boys in certain disciplines (Chambers and Schreiber, 2004). In a meta analyses that used 100 sources with 259 independent effect sizes suggested that gender differences in Mathematics achievement are small and differences favoring men emerge in high school and in college (Hyde et al., 1990). In a more recent study (Lindberg et al., 2010) gender difference ranged between -0.15 and +0.22 (negative values indicating superior achievement by females). Supporting the view that males and females perform similarly in mathematics, although larger positive values were found at the male group.
Similarly, a meta-analysis study with scholastic achievement found a female advantage for language courses (Voyer and Voyer, 2014).

The variable that predicted the greatest amount of decrease on academic achievement at the first level was school failure. Another outcome frequently related to school failure-school dropout-showed a lower but significant negative effect over 5 th graders achievement both in Portuguese and Math in our study. These results suggest a shortcoming in Brazilian education policy because students that fail attend the same classes in the next year with no adaptation to the program aimed to deal with student's individual deficiencies (de Leon and Menezes-Filho, 2001). Motivation is also an important element to be considered (Fortier et al., 1995). Low motivation may be related to school failure and bad school achievement, establishing a vicious circle.

It is important to highlight that LDB established that Elementary Education in Brazil might be organized in grades or cycles (among other options), the latter implying continuous progression and reduction of school failure. Therefore, each state Education Department is free to adopt a modality-either organizing Elementary Education in cycles, solely in grades, or a combined model. As discussed previously, Brazil's Education System is decentralized and encompasses three levels (city, state, and union), each with its own subsystems in each level of education. Currently, only four Brazilian states adopt grades for the whole range of Elementary Education-the other 20 states and the Federal District adopt cycles for at least the first years of schooling, and four of them adopt cycles throughout the level. The 2013 School Census revealed that $21.3 \%$ of primary schools in Brazil were organized in cycles (Ministério da Educação, 2014). This rate meets UNESCO’s “Education for all in 2015" (United Nations Educational Scientific and Cultural Organization-UNESCO, 2007) recommendation to introduce continuous progression within cycles in over $10 \%$ of schools in Brazil, thereby reducing failure and retention-and our results support the findings that indicate the detrimental effect of failure on school achievement among 5th graders.

Nevertheless, continuous progression divides opinions between educators and experts in Brazil, especially because implementation of the strategy is not always accompanied by recommended educational practices such as reinforcement and recovery activities, alternative means and adaptation, teachers training, and therefore likely (Jacomini, 2004; Neves and Boruchovitch, 2004); results in a condition labeled "automatic promotion" (Gadotti, 2003) usually associated with low academic achievement. Menezes-Filho et al. (2009) compared achievement in Prova Brasil 2005 by graded school students vs. students of schools that adopted cycles (therefore continued progression). The study showed that the effect of cycles is significant in reducing dropout rates for all levels of education. On the other hand, the effect of continued progression was not significant on 5th graders' achievement in Prova Brasil 2005, and had a negative and significant impact on the achievement of 9th graders. A study commissioned in São Paulo, the first state to adopt cycles in full length in Elementary Education, consulted teachers, parents and students from all state regions and found that continuous progressions was the second most important 
problem faced by public schools, according to teachers. Teachers, parents and students agreed that security issues/violence was the most important problem (APEOESP, 2014).

Students extensively engaged in household chores and work related activities performed worse than the other students. These findings corroborate a previous study by Alberto et al. (2011) who found that children and adolescent workers have lower school attendance, with consistently poor consequences in learning. Apart from worse achievement in standardized tests, children living under impoverished conditions face a higher level of stress, affecting their memory, learning, and achievement. Moreover, they have higher rates of morbidity and chronic diseases, and more emotional and behavior problems (Moore et al., 2009; Lefmann and Combs-Orme, 2014).

For instance, in 1988 when the new Federal Constitution was enacted, about $15 \%$ of 7-14 year old Brazilians were not enrolled in school. The last national census, carried out in 2010, showed a significant decrease in out-of-school children/adolescents rate, reaching $3.3 \%$. The most affected by exclusion were the $4-5$ and 15-17 age groups. Reasons for being out of school were similar throughout age groups and mirrored the country's grave social inequalities - the majority were poor, afro-descendant children from parents or guardians with little or no education, living in rural areas (UNICEF, 2014). In accordance with these findings, school failure, ethnicity (afro-descendants) and child labor were the most detrimental factors on 5th grade student achievement as measured by Prova Brasil 2011.

Student's culture seeking behaviors (attending museums, cinemas, theaters) showed a negative relationship with student's achievement in Mathematics and Portuguese. These results contradict (Gaddis, 2013) investigation in which typical operationalizations of cultural capital (high-arts participation and reading habits) has positive effects on grade point average. However, these findings might be due to type of cultural habits experienced by students since it was not possible to assess the qualitative aspects of this variable, for instance the kind of books read or movies seen.

\section{Second Level}

All the details of the variables at the second level (Class) and their relationship with academic achievement are displayed in Table 4.

The first two variables to have a significant relationship with academic achievement in Mathematics and Portuguese are teacher ethnicity $\left[\chi_{(M)}^{2}=113.99, p<0.001 ; \chi_{(P)}^{2}=59.77\right.$, $p<0.001]$ and gender $\left[\chi_{(M)}^{2}=14.37, p<0.001 ; \chi_{(P)}^{2}=\right.$ $18.14, p<0.001]$. The results indicate that better achievement is obtained when teachers are white and male.

Discussions about the attempt to explain differences in achievement for Portuguese and Mathematics tasks must take into account the influence of teacher's characteristics. According to Dee (2007), some theories suggest that many of these differences are related to the teacher's gender. It is believed that students were more well behaved and performed better when taught by a teacher of the same gender. Conversely, Antecol et al. (2015) bring a review about findings concerning the impact of teachers on different academic results, as well as teacher's gender influence on students from primary education. Their results showed that female teachers have a negative influence to scores of elementary school students in mathematics compared to male teachers.

Empirical evidence resulting from research in this field, as showed by Escardibul and Mora (2013), point out that an accurate determination of the relationship between gender of teachers and student achievement in primary and secondary education is yet to be established. It is prudent to consider that our objective was to analyze the best hierarchical model that may substantiate political policies aiming to improve the achievement of students in Portuguese and Mathematics, and not focused on exploring the determinants of gender influence of teachers on the achievement of students.

Regarding the ethnicity variable, according to Dee (2004), some theories suggest that ethnic interaction between teachers and students can influence the achievement of those in various ways. Students tend to trust and respect those who share certain characteristics, making learning easier. Also a teacher of the same ethnic group can be seen as an effective role model, increasing confidence and enthusiasm for learning. Conversely, there is little direct empirical evidence to support these claims. This study linked students with teachers of the same ethnicity (i.e., afrodescendant teachers with black students, and so on), which proved to be influential in the achievement of students. However, it was thought a posteriori that these differences could be attributed to not directly observed qualitative differences.

A possible explanation for our results indicating that white teachers have a positive influence student achievement may be related to better access to education and qualification for whites as opposed to other ethnicities. Thus, having better educational opportunities, white teachers might develop a better technical training which may have contributed to the observed result.

The amount of time that the teacher worked per week $\left[\chi_{(M)}^{2}\right.$ $\left.=53.64, p<0.001 ; \chi_{(P)}^{2}=48.91, p<0.001\right]$ was also significantly associated with student achievement. The worst performing group in both subjects were those students taught by teachers who worked " $30 \mathrm{~h}$ per week." The structure of the response options themselves must be addressed, since the choice of defining some categories as intervals and others as a single value might add unaccounted bias to the results. Moreover, the item also referred to the total amount of time devoted exclusively to teaching, not accounting for administrative work or time spent preparing classes.

As discussed by Arelaro et al. (2014) there are different types of contracts for teachers in Brazil. In most, hours spent in extracurricular activities are assumed to be part of the workload, and we cannot know if they were considered by teachers as working hours when answering the question. The authors also state that in most schools the "teaching hour" is equivalent to a 45 -min class, which would mean that a $30 \mathrm{~h}$ a week contract implies in 22.5 "in-class" teaching hours. Again, this uncertainty was likely transferred to the data, adding noise to the observed results. This might explain the lack of a clear trend concerning the different levels of the weekly workload variable. Further 
TABLE 4 | Standardized coefficients, chi-square, and significance levels of the second level variables.

\begin{tabular}{|c|c|c|c|c|c|c|c|}
\hline \multirow[t]{2}{*}{ Variable } & \multirow[t]{2}{*}{ Category } & \multicolumn{3}{|c|}{ Portuguese Language } & \multicolumn{3}{|c|}{ Mathematics } \\
\hline & & $\chi^{2}$ & $\beta$ & $t$ & $\chi^{2}$ & $\beta$ & $t$ \\
\hline Teacher's ethnicity & Does not know & $59.77^{\star \star \star}$ & -3.04 & -1.33 & $113.99^{\star \star \star}$ & -3.68 & -1.42 \\
\hline \multirow[t]{4}{*}{ Baseline: White } & Asian & & -1.49 & -1.18 & & -1.22 & -0.86 \\
\hline & Black & & -1.66 & -1.18 & & -3.10 & -4.23 \\
\hline & Brazilian Indian & & -5.11 & -2.42 & & -6.47 & -2.68 \\
\hline & Brown & & -2.87 & -7.40 & & -4.51 & -10.30 \\
\hline Teacher working hours per week & $20 \mathrm{~h}$ per week & $48.91^{\star \star \star}$ & -0.64 & -0.39 & $53.64^{\star \star \star}$ & -1.19 & -0.63 \\
\hline \multirow[t]{7}{*}{ Baseline: Less than } & 21-24 h per week & & 4.12 & 2.31 & & 5.80 & 2.87 \\
\hline & $25 \mathrm{~h}$ & & -0.18 & -0.10 & & -0.01 & -0.01 \\
\hline & 26-30 h per week & & 1.94 & 0.98 & & 1.40 & 0.62 \\
\hline & $30 \mathrm{~h}$ per week & & -0.74 & -0.44 & & -1.30 & -0.67 \\
\hline & 31-39h per week & & 2.10 & 1.23 & & 2.98 & 1.54 \\
\hline & $40 \mathrm{~h}$ per week & & 2.14 & 1.34 & & 1.04 & 0.58 \\
\hline & More than $40 \mathrm{~h}$ per week & & 2.42 & 1.51 & & 1.03 & 0.57 \\
\hline General pedagogic practice & Numerical & $35.14^{\star \star \star}$ & 1.07 & 5.92 & $35.44^{\star \star \star}$ & 1.21 & 5.95 \\
\hline Teacher Gender & Female & $18.14^{\star \star \star}$ & 2.56 & 4.25 & $14.37^{\star \star \star}$ & 2.48 & 3.79 \\
\hline \multicolumn{8}{|l|}{ Baseline: Male } \\
\hline Teacher's level of education & High school & $16.89^{\star \star \star}$ & -1.04 & -0.18 & $17.86^{\star \star \star}$ & 1.93 & 0.30 \\
\hline Baseline: elementary school & Completed university & & 2.31 & 0.40 & & 5.73 & 0.90 \\
\hline Number of schools the teacher works & Two & $12.18^{\star \star \star}$ & -1.47 & -3.39 & $12.18^{\star \star \star}$ & -1.68 & -3.42 \\
\hline \multirow[t]{2}{*}{ Baseline: One } & Three & & -0.71 & -0.63 & & -1.73 & -1.38 \\
\hline & Four or more & & 0.40 & 0.21 & & -3.02 & -1.43 \\
\hline Teacher's contract type & Temporary (no formal contract) & $9.50^{\star}$ & -4.31 & -2.19 & $18.09^{\star *}$ & -3.33 & -1.47 \\
\hline \multirow[t]{2}{*}{ Baseline: Statutory } & Temporary (with formal contract) & & -1.04 & -1.92 & & -2.05 & -3.38 \\
\hline & CLT (consolidation of labor laws) & & 0.34 & 0.60 & & 1.02 & 1.58 \\
\hline
\end{tabular}

Significance levels: ${ }^{\star * *} p<0.001 ;{ }^{\star \star} p<0.01 ;{ }^{*} p<0.05$.

assessment of the interactions between this variable and the number of schools a given teacher works at might clarify the relationship between worked hours and achievement.

The variable that accounts for the number of schools a teacher works is directly related to the number of hours and displays a more interpretable trend $\left[\chi_{(M)}^{2}=12.18, p<0.001 ; \chi_{(P)}^{2}=12.18\right.$, $p<0.001]$. With the exception of Portuguese teachers working at four or more schools, working in more schools was associated with worse student achievement. This pattern can be explained by increased stress and less time available for class preparation and further qualification of the teacher (Skaalvik and Skaalvik, 2011).

The diversity of pedagogic practices used by the teacher was also deemed important $\left[\chi_{(M)}^{2}=35.44, p<0.001 ; \chi_{(P)}^{2}=\right.$ 35.14, $p<0.001]$. The variable assessed whether a teacher uses in-class aids, such as computers, the internet or comic books. The relationship was positive, which means that better achievement was expected from those students taught by teachers who incorporated learning aids. Recent developments in the literature support these findings, and further states that the effects of learning aids can be particularly effective for students with lower achievement (Sung et al., 2015). The authors also report improvement in pupils' attitudes toward the subject after contact with such practices. Attitudes were not assessed directly by SAEB but could also positively influence achievement in the long term (Chou et al., 2015).
The influence of the level of qualification of a teacher was also relevant to achievement $\left[\chi_{(M)}^{2}=17.86, p<0.001 ; \chi_{(P)}^{2}\right.$ $=16.89, p<0.001]$. There is a general positive trend in achievement for students of increasingly qualified teachers, with some unexpected deviations from said trend. One exception was a lower average score in Portuguese students of teachers who graduated high school when compared to those who studied up to elementary school only. Since the requirements for teacher qualification increased with time in Brazil this may be explained by the amount of years of experience those older teachers have compensating for the lack of formal education, although that would require further investigation to confirm. This difference is not observed in Mathematics, which could be associated with the modernization of teaching techniques, as discussed by Fiorentini (2005), that could outweigh the influence of experience.

\section{Third Level}

All the details of the variables at the third level (School) and their relationship with academic achievement are displayed in Table 5.

The school level variables that most impacted achievement were that ones related to national programmes aimed at the reduction of school dropout $\left[\chi_{(M)}^{2}=61.32, p<0.001 ; \chi_{(P)}^{2}\right.$ $=46.68, p<0.001]$ and school support programmes focused on tutoring and learning difficulties monitoring $\left[\chi_{(M)}^{2}=30.30\right.$, $\left.p<0.001 ; \chi_{(P)}^{2}=14.13, p<0.001\right]$. Over the last two 
TABLE 5 | Standardized coefficients, chi-square, and significance levels of third level variables.

\begin{tabular}{|c|c|c|c|c|c|c|c|}
\hline \multirow[b]{2}{*}{ Variable } & \multirow[b]{2}{*}{ Category } & \multicolumn{3}{|c|}{ Portuguese language } & \multicolumn{3}{|c|}{ Mathematics } \\
\hline & & $\chi^{2}$ & $\beta$ & $\mathbf{T}$ & $\chi^{2}$ & $\beta$ & $\mathbf{t}$ \\
\hline Information and communications technology & Numerical & $75.26^{\star \star \star}$ & 2.06 & 8.67 & $90.86^{\star \star \star}$ & 2.62 & 9.53 \\
\hline $\begin{array}{l}\text { Presence of school dropout program } \\
\text { Baseline: None }\end{array}$ & Yes & $46.68^{\star \star \star}$ & -2.89 & -6.83 & $61.32^{\star \star \star}$ & -3.87 & -7.83 \\
\hline Public Areas & Numerical & $25.83^{\star \star \star}$ & 1.08 & 5.08 & $28.18^{\star \star \star}$ & 1.32 & 5.30 \\
\hline School food service & Numerical & $23.30^{\star \star \star}$ & 1.02 & 4.82 & $39.71^{\star \star \star}$ & 1.56 & 6.30 \\
\hline Violence inside school & Numerical & $17.58^{\star \star \star}$ & -1.09 & -4.19 & $20.69^{\star \star \star}$ & -1.38 & -4.19 \\
\hline $\begin{array}{l}\text { Presence of school supporting program for students } \\
\text { Baseline: None }\end{array}$ & Yes & $14.13^{\star \star \star}$ & 2.53 & 3.76 & $30.30^{\star \star \star}$ & 4.28 & 5.50 \\
\hline Actions to prevent violence & Numerical & $12.00^{\star \star \star}$ & 0.69 & 3.46 & $13.91^{\star \star \star}$ & 0.87 & 3.73 \\
\hline
\end{tabular}

Significance levels: ${ }^{* \star *} p<0.001 ;{ }^{\star \star} p<0.01 ;{ }^{*} p<0.05$.

decades, far-reaching welfare measures and social programmes were developed to eradicate extreme poverty, most of which have contributed significantly to preventing school dropout and supporting families who consistently send their children to school. Some national programs, such as Brazil's National School Feeding Programme and Bolsa Familia have also helped reduce the school dropout rate. According to the INEP Bolsa Familia alone has been responsible for a decrease of as much as $36 \%$ of school dropout rates.

The presence of regional and national school support programs has led Prova Brasil scores to increase significantly for both Portuguese and Mathematics. Most of these programs are directly associated with investments in information/communication technology, which have also provided small, but significant improvements to the student's achievement $\left[\chi_{(M)}^{2}=90.86, p<0.001 ; \chi_{(P)}^{2}=75.26\right.$, $p<0.001]$. The National Program of Educational Technology (ProInfo) is one of the most important policies focused on promoting the educational use of information technology by students in public schools. Federal government provides states or municipalities with the equipment needed to set up computer labs, which in turn contribute with the necessary infrastructure and faculty training on how to use the technology.

The relationship between infrastructure (i.e., and academic achievement in Brazilian large-scale assessments) has been extensively investigated. Research in developed countries indicate that infrastructure does not have a significant effect on the academic achievement (see Sammons, 1995, and OECD, 2014b for example). According to studies by Velez et al. (1994), Espósito et al. (2000), Barbosa et al. (2001), van Batenburg and Laros (2002), Biondi and Freitas (2007), Franco et al. (2007), Murillo (2007), Murillo and Román (2011), and Paget et al. (2016), only a modest relationship was found between these two variables. Another important study carried out by OECD (2014b) on the Programme for International Student Assessment (PISA) found only a weak relationship between educational resources and student achievement. In this study, there was more variance explained by the quality of human resources than by material and financial resources, similar to results found among industrialized nations. Albernaz et al. (2002) also stated from their findings that the more qualified the teachers are, the better the general results for academic achievement.

School public areas also highly significant for both Portuguese and Mathematics $\left[\chi_{(M)}^{2}=25.83, p<0.001 ; \chi_{(P)}^{2}=28.18\right.$, $p<0.001]$. This variable measures the presence of laboratories, libraries, playgrounds, cafeterias, and sports courts. This finding is consistent with the studies conducted by Franco and Bonamino (2005), Bezerra and Kassouf (2006), Marzocchi and Oliveira (2009), Neji et al. (2014), and Paget et al. (2016) who agree that laboratory facilities, libraries, and audiovisual materials had a substantial effect on school achievement. However, although school infrastructure can play a significant role in improving the quality of education at large, Franco and Bonamino (2005) highlight that these resources themselves are not sufficient to ensure the increase of student achievement, as this occurs due to the interaction of different factors and it depends on whether they are effectively and consistently used by students. Further, Hanushek (2005) suggests that the effect of infrastructure and resources on achievement varies with the level present across the educational system.

Public policies that have a positive impact in the learning capabilities of the students are necessary to increase school achievement. According to Soares and Alves (2003), factors that impact cognitive achievement can be categorized into four groups: pedagogical projects, school structure, family, and personal aspects of the student.

\section{CONCLUSION}

Findings presented in this study may contribute to identifying which variables are most influential on Brazilian student's achievement and therefore may serve as a guide in future decisions about educational policies. Prova Brasil aims to provide information on students' educational achievement across different stages of their development and how several socioeconomic variables are related to their performance. The variables examined in this study were addressed in a three level model (student, class, and school) in order to reflect 
the within school complexities of educational interactions-a common critique of school effectiveness studies that do not employ this methodology (Goldstein and Woodhouse, 2000). Additionally, the relatively large number of factors examined in this study further addresses critiques that there is little evidence to support simplified and short lists of factors that contribute to educational achievement and school effectiveness (Goldstein and Woodhouse, 2000).

It should be noted that the use of standardized tests themselves have a wider implication for education, appropriate teaching, and all relevant policies. Such arguments are naturally highly valuable and relevant, and should be considered alongside any and all arguments made in this body of work. The limitations of large scale testing data are numerous and have been addressed extensively in the literature. Critiques range from the limitations of the use of large scale multiple choice testing as a measurement of educational quality or achievement (see Sayed and Kanjee, 2013 for example), to the limitations of the predictor variables themselves (see Wiliam, 2008 for example), and of course the over-simplification of the complex and dynamic processes that characterize education and learning-a limitation acknowledged even by the foundational researchers into school effectiveness factors (see Becker, 1964; Harbison and Hanushek, 1992 for example). However, for the purposes of the research and recommendations made here, arguments focus on the idea of approaching policy utilizing an increasingly-used analytical technique that could be applied to any measure of performance (or comparable outcome measure of interest). As such, we state that this piece does not seek to argue for or against the use of Prova Brasil itself as a sufficient indicator, but rather, assumes its use as one.

In summary, the significant variables of the first level cluster around two main groups. The first one concerns the time available or dedicated to studies. As a general trend, more time dedicated to other activities not directly related to schoolwork has a negative association with achievement scores, and the opposite is also observed. The second cluster is concerned with the influence of parents in the student's academic life. The positive influence can be either direct through parental involvement in homework or indirect, through the level of education of parents, for instance. The second level variables clustered around the conditions of the teacher's working environment and also around their qualifications. In general, more qualification and better working conditions correlate positively with Prova Brasil scores. The third level variables are mostly associated with the quality of school infrastructure, in which positive trends are surprisingly not ubiquitous (e.g., Didactic Materials). These results both refine and advance the current research on school effectiveness studies in the developing world. While they find some basis in international trends (see Scheerens, 2000, 2001), this study represents one of a very limited number of English language studies using Prova Brasil data to examine important factors of progression for Brazilian students (see Paget et al., 2016 for example). This study, therefore, permits a broader comparison between Brazilian data and other large scale international studies (see Segretin et al., 2009 for example).
The results are presented by level due to the type of statistical technique employed in this study, i.e., Multilevel Modeling. The critical benefit in using the MLM approach in Brazil is its ability to present critical findings across the complex and many-dimensional domains relevant to education in a large and diverse population. When applied to educational testing, MLM produces relevant levers for policymakers. Utilizing levers is only possible when understanding why any particular finding may have occurred as well as comparator results for establishing priority. As such, the level-based analysis is particularly vital for identifying potential solutions out of a range of possible options, and establishing clear targets for improvement, which has clearly provided impetus for schools in Brazil.

Despite considerable investment and restructuring of the Brazilian educational system over the last 20 years, Brazil continues to lag behind its OECD counterparts on international educational ranking systems (Bruns et al., 2012). According to 2012 PISA reports, education in Brazil scored among the 10 lowest in both mathematics and reading (PISA, 2012). Through the continuous monitoring and analysis of Prova Brasil data, the Brazilian Ministry of Education is in a position to target future policies and funding where it may be best used in order to address continued deficiencies. The results of this study may help direct the Ministry's focus to some of the most important variables of student achievement. This, of course, is not a fool-proof system. For example, Silva et al. (1993) state that the reason behind Brazil's low educational achievement might be closely related to the lack of investments in educational structure, observed, for instance, in high budget programs that lack organization and proper control from authorities. These programs are then discontinued for not achieving the expected goals or become somewhat demoralized for the same reasons. At the very least, educational policies can be difficult to formulate and implement given the dynamic, complex, and differentiated settings in which teaching and learning takes place (Teddlie, 1994; Teddlie et al., 2000). The significance of large-scale analyses such as the one conducted in this study, however, can offer directions for further study with more sensitive instruments.

A few limitations must be addressed from the outputs of this research. Firstly, even though there is a nationwide curriculum that is expected to be followed by every Brazilian School, no adaptations or statistical techniques (e.g., Differential Item Functioning) were utilized to compensate or identify occasional differences in how subjects are taught to students.

Another relevant structural limitation concerns the absence of variables that seek to assess individual characteristics on a personal level. According to Soares and Alves (2003), personal aspects of the students impact cognitive abilities. Our concern lies on the underrepresentation of this group of variables on the socioeconomic questionnaires of Prova Brasil. Several authors argue that the low amounts of explained variance in studies in the field of educational are related to the lack of data on individual characteristics, such as cognitive abilities and other personality related features as motivation and persistency (Teddlie and Reynolds, 2000; Soares et al., 2001).

As this study addresses a wide range of variables that influence academic achievement from a broader 
perspective, only random intercept models were utilized for achievement prediction. Random slope and multilevel models with interactions between variables were therefore not considered. Moreover, only the overall scores for the whole of the country were taken into account, but not scores by regions or states. Considering these limitations, future research exploring further relations among variables from different levels and focused on states and regions is recommended.

\section{AUTHOR CONTRIBUTIONS}

As the first author, IM contributed to organize and write all the sections of the paper. SS contributed to organize the literature review, discussion, and conclusion. VD collaborated to carry

\section{REFERENCES}

Albernaz, A., Ferreira, F. H. G., and Franco, C. (2002). Qualidade e Equidade na Educação Fundamental Brasileira. Texto para discussão n ${ }^{\circ} 455$. Available online at: http://www.econ.puc-rio.br/pdf/td455.pdf

Alberto, M. F. P., Santos, D. P., Leite, F. M., and Lima, J. W. (2011). O trabalho infantil doméstico e o processo de escolarização. Psicol. Soc. 23, 293-302. doi: 10.1590/S0102-71822011000200010

Allison, P. D. (2002). Missing Data Series: Quantitative Applications in the Social Sciences. Thousand Oaks, CA: Sage.

Andrade, J. M., and Laros, J. A. (2007). Fatores associados ao desempenho escolar: estudo multinível com dados do SAEB/2001. Psicol. Teoria Pesquisa 1, 33-42. doi: $10.1590 / \mathrm{s} 0102-37722007000100005$

Antecol, H., Eren, O., and Ozbeklik, S. (2015). The effect of teacher gender on student achievement in primary school. J. Labor Economics 33, 1-35. doi: 10.1086/677391

APEOESP (2014). Violência Nas Escolas: O Olhar Dos Professores. CEPES: Centro de Estudos e Pesquisas Educacionais, Sindicais e Gerenciamento do Banco de dados da APEOESP (Sindicato dos Professores do Ensino Oficial do Estado de São Paulo). Available online at: http://www.apeoesp.org.br/publicacoes/ observatorio-da-violencia/caderno-violencia-nas-escolas-analise-da-pesquisa

Arelaro, L. R. G., Jacomini, M. A., Souza, N. A. D., and Santos, K. A. (2014). Condições do trabalho docente: uma análise da carreira na rede municipal de ensino de São Paulo. Rev. Brasil. Est. Pedagóg. 95, 197-217. doi: 10.1590/S2176-66812014000100011

Arias, O., Yamada, G., and Tejerina, L. (2004). Education, family background and racial earnings inequality in Brazil. Int. J. Manpower 25, 335-374. doi: 10.1108/01437720410541443

Barbosa, M., Fernandes, C., and Franco, C. (2001). "A escola brasileira faz diferença? Uma investigação dos efeitos da escola na proficiência em matemática dos alunos da $4^{\mathrm{a}}$ série," in Avaliação, Ciclos $e$ Promoção na Educação, ed C. Franco (Porto Alegre: Artmed), $155-172$.

Becker, G. (1964). Human Capital: A Theoretical and Empirical Analysis, with Special Reference to Education. New York, NY: National Bureau of Economic Research.

Bezerra, M. G., and Kassouf, A. L. (2006). "Anailise dos Fatores que Afetam o Desempenho Escolar nas Escolas das Aireas Urbanas e Rurais do Brasil," in 44th Congress, July 23-27, 2006, no. 144811, (Fortaleza: Sociedade Brasileira de Economia, Administracao e Sociologia Rural (SOBER)).

Biondi, R. L., and Freitas, R. C. (2007). Atributos escolares e o desempenho dos estudantes? uma análise em painel dos dados do Saeb. Brasília, DF: Instituto Nacional de Estudos e Pesquisas Educacionais Anísio Teixeira.

Brasil, Ministério da Educação (2008). PDE: Plano de Desenvolvimento da Educação: Prova Brasil: Ensino Fundamental: Matrizes de Referência, Tópicos e Descritores, Vol. 193. Brasília: MEC, SEB, Inep. out the data analysis and to describe the results. TV and EF collaborated to write the results and discussion. CP as a specialist in educational policies was responsible to review the whole of the paper and to contribute to the discussion and conclusions. $\mathrm{KR}$ was responsible to discuss educational policies in light of his experience on this topic and contributed to the whole of the paper.

\section{ACKNOWLEDGMENTS}

The authors are grateful to the National Institute for Educational Studies and Research "Anísio Teixeira” (INEP) and the National Council for Scientific and Technological Development $(\mathrm{CNPq})$ and for providing financial support for this study.

Brasil, Ministério da Educação (2015). Prova Brasil Datasets Website. Available online at: http://download.inep.gov.br/microdados/microdados_prova_brasil_ 2011.zip

Bruns, B., Evans, D., and Luque, J. (2012). Achieving World-Class Education in Brazil: the Next Agenda. Washington, DC: World Bank (Directions in Development).

Caldas, S. J., and Bankston, C. L. III. (1997). The Effect of school population socioeconomic status on individual student academic achievement. J. Educ. Res. 90, 269-277. doi: 10.1080/00220671.1997.10544583

Castelar, P. U. C., Monteiro, V. B., and Lavor, D. C. (2012). Um Estudo sobre as Causas de Abandono Escolar nas Escolas Puiblicas de Ensino Meidio no Estado do Cearai. Fortaleza: Anais do VIII Encontro - Economia do Cearaì em Debate.

Castro, J. A. (1998). O Fundef e o Seu Impacto No Financiamento Do Ensino Fundamental. Textos Para Discussão n. 604, 1-46. in del Barreto, Corbucci, A. R., and Roberto, P. (1998), A Reestruturação das Políticas Federais Para o Ensino Fundamental: Descentralização e Novos Mecanismos de Gestão. Textos Para Discussão n. 745, 26.

Castro, J. A., and Menezes, R. M. (2003). Avanços e Limites na Gestão da Política Federal de Ensino Fundamental nos anos 1990. Brasília: Instituto Pesquisa Econômica Aplicada.

Castro, R. F. (2009). Eficácia e Equidade em Escolas Públicas na Bahia 2008. Unpublished Doctoral dissertation, Universidade Federal da Bahia.

Cervini, R. (2002). Desigualdades socioculturales en el aprendizaje de Matemática y Lengua de la educación secundaria en Argentina: Un modelo de tres niveles. Rev. Electrón. Invest. Eval. Educ. 8, 135-158. Available online at: http://www.uv. es/relieve/v8n2/RELIEVEv8n2_1.htm

Cervini, R. (2006). Los efectos de la escuela y del aula sobre el logro en Matemática y en Lengua de la educación secundaria. Un modelo multinivel. Perfiles Educ. $28,68-97$.

Chambers, E. A., and Schreiber, J. B. (2004). Girls' academic achievement: varying associations of extracurricular activities. Gender Educ. 16, 327-346. doi: 10.1080/09540250042000251470

Chou, Y., Yen, H., and Yen, H. (2015). The effectiveness of teaching aids for elementary students' renewable energy learning and an analysis of their energy attitude formation. Int. J. Environ. Sci. Educ. 10, 39-49. doi: 10.12973/ijese.2015.229a

Cliffordson, C., and Gustafsson, J. E. (2010). "Effects of schooling and age on performance in mathematics and science: a between-grade regression discontinuity design with instrumental variables applied to Swedish TIMSS 1995 data," in Fourth IEA International Research Conference (IRC-2010) (Gothenburg).

Cooper, H., Robinson, J. C., and Patall, E. A. (2006). Does homework improve academic achievement? A synthesis of research, 1987-2003. Rev. Educ. Res. 76, 1-62. doi: 10.3102/00346543076001001

Couri, C. (2010). Nível socioeconômico e cor/raça em pesquisas sobre efeitoescola. Estudos Avaliação Educ. 21, 449-472. doi: 10.18222/eae214720102458 
de Leon, F., and Menezes-Filho, N. (2001). "Reprovação, avanço e evasão escolar no Brasil," in Cultura, 417-452. Available online at: http://www.ppe.ipea.gov. br/index.php/ppe/article/view/138/73

Dee, T. S. (2004). The race connection: are teachers more effective with students who share their ethnicity? Educ. Next 4, 52-59. Available online at: http://eric. ed.gov/?id=EJ763248

Dee, T. S. (2007). Teachers and the gender gaps in student achievement. J. Hum. Res. 42, 528-554. doi: 10.3386/w11660

Dourado, L. F. (2002). Reforma do estado e as políticas para educação superior no Brasil nos anos 90. Educ. Soc. Campinas 23, 234-252. doi: 10.1590/s0101-73302002008000012

Eitle, T. M. (2005). Do gender and race matter? Explaining the relationship between sports participation and achievement. Soc. Spectrum 25, 177-195. doi: $10.1080 / 02732170590883997$

Espósito, Y., Davis, C., and Nunes, M. (2000). Sistema de avaliação do rendimento escolar: o modelo adotado pelo Estado de São Paulo. Rev. Brasil. Educ. 1, 25-53.

Felicio, F. (2010). Fatores Associados ao Sucesso Escolar: Levantamento, Classificação e Análise dos Estudos Realizados no Brasil. São Paulo: Fundação Itaú Social. Available online at: http://www.fundacaoitausocial.org. br/_arquivosestaticos/FIS/pdf/fase_ultima_versao.pdf

Fernandes, D. C. (2004). Race, socioeconomic development and the educational stratification process in Brazil. Res. Soc. Stratific. Mob. 22, 365-422. doi: 10.1016/S0276-5624(04)22012-1

Ferrão, M. E. (2003). Introdução aos Modelos de Regressão Multinível em Educação. Campinas, SP: Komedi.

Ferrão, M. E. B., and Fernandes, C. (2001). “A escola brasileira faz diferença? Uma investigação dos efeitos da escola na proficiência em Matemática dos alunos da $4^{\mathrm{a}}$ série," in Promoção, Ciclos e Avaliação Educacional, ed C. Franco, (Org.) (Curitiba: ArtMed).

Ferrer, G. (2006). Sistemas de Evaluación de Aprendijazes en America Latina: Balances y Desafios. Santiago: PREAL.

Fiorentini, D. (2005). A formação matemática e didático-pedagógica nas disciplinas da licenciatura em matemática. Rev. Educ. PUC Campinas 18, 107-115. Available online at: http://200.18.252.94/seer/index.php/reveducacao/ article/view/266

Fortier, M., Vallerand, R., and Guay, F. (1995). Academic motivation and school performance: toward a structural model. Contemp. Educ. Psychol. 20, 257-274. doi: $10.1006 /$ ceps.1995.1017

Franco, C., and Bonamino, A. (2005). A Pesquisa Sobre Características de Escolas Eficazes no Brasil: Breve Revisão dos Principais Achados e Alguns Problemas Emaberto. Educação, Vol. 1. Available online at: http://www.lambda.maxwell. ele.puc-rio.br/7378/7378.PDF

Franco, C., Fernandes, C., Soares, J. F., Beltrão, K., Barbosa, M. E., and Alves, M. T. G. (2003). O referencial teórico na construção dos questionários contextuais do Saeb 2001. Estud. Aval. Educ. 28, 39-74. doi: 10.18222/eae028200 32169

Franco, C., Ortigão, I., and Albernaz, A. (2007). Qualidade e equidade em educação: reconsiderando o significado de fatores intra-escolares. Ensaio 15, 277-297. doi: 10.1590/s0104-40362007000200007

Gaddis, S. M. (2013). The influence of habitus in the relationship between cultural capital and academic achievement. Soc. Sci. Res. 42, 1-13. doi: 10.1016/j.ssresearch.2012.08.002

Gadotti, M. (2003). Por que progressão continuada. Rev. Brasil. Estud. Pedagógicos 84, 221-224. Available online at: http://emaberto.inep.gov.br/index.php/rbep/ article/viewFile/899/874

Garzon, G. (2006). Social and Cultural Foundations of American Education. Wikibooks. Available online at: https://en.wikibooks.org/wiki/Social_and_ Cultural_Foundations_of_American_Education

Gelman, A., and Hill, J. (2007). Data Analysis using Regression and Multilevel/Hierarchical Models. New York, NY: Cambridge University Press.

Goldstein, H., Rasbash, J., Yang, M., Woodhouse, G., Pan, H., Nuttal, D., et al. (1993). A multilevel analysis of school examination results. Oxford Rev. Educ. 19, 425-433. doi: 10.1080/0305498930190401

Goldstein, H., and Woodhouse, G. (2000). School effectiveness research and educational policy. Oxford Rev. Educ. 26, 353-363. doi: 10.1080/713688547

Gray, J., Jessons, J., and Sime, N. (1990). Estimating differences in the examination performances of secondary schools in six LEAs: a multi-level approach to school effectiveness. Oxford Rev. Educ. 16, 137-158. doi: 10.1080/0305498900160201

Hanushek, E. (2005). Economic Outcomes and School Quality. Paris: Education Policy Series. UNESCO.

Harbison, R., and Hanushek, E. (1992). Educational Performance of the Poor: Lessons from Rural Northeast Brazil. Oxford: Oxford University Press.

Hasenbalg, C., and Valle Silva, N. (1990). Raça e oportunidades educacionais no Brasil. Cadernos Pesquisa 73, 5-12.

Hattie, J. (2009). Visible Learning for Teachers: Maximizing Impact on Learning. London: Routledge.

Hyde, J., Fennema, E., and Lamon, S. (1990). Gender differences in mathematics performance: a meta-analysis. Psychol. Bull. 107, 139-139. doi: 10.1037/0033-2909.107.2.139

Jacomini, M. A. (2004). A escola e os educadores em tempo de ciclos e progressão continuada: uma análise das experiências no estado de São Paulo. Educação Pesquisa 30, 401-418. doi: 10.1590/S1517-97022004000300002

Jesus, G. R., and Laros, J. A. (2004). Eficaìcia escolar: regressão multinível com dados de avaliação em larga escala. Avaliação Psicoloigica 3, 93-106. Available online at: http://pepsic.bvsalud.org/pdf/avp/v3n2/v3n2a04.pdf

Jeynes, W. H. (2002). Examining the effects of Parental absence on the academic achievement of adolescents: the challenge of controlling for family income. J. Family Econ. Issues 23, 189-210. doi: 10.1023/A:1015790701554

Kahlenberg, R. D. (2006). "The history of collective bargaining among teachers" in Collective Bargaining in Education: Negotiating Change in Today's School, eds J. Hannaway and Rotherham (Cambridge, MA: Harvard Education Press), 7-25.

King, G., Honaker, J., Joseph, A., and Scheve, K. (2001). Analyzing incomplete political science data: an alternative algorithm for multiple imputation. Am. Political Sci. Assoc. 95, 49-69. Available online at: https://www.cambridge. org/core/article/analyzing-incomplete-political-science-data-an-alternativealgorithm-for-multiple-imputation/9E712982CCE2DE79A574FE98488F212B

Kirkup, J. (2008). “Middle-class children resentful at being pushed to succeed," in Telegraph. Available online at: http://www.telegraph.co.uk/education/3330301/ Middleclass-children-resentful-at-being-pushed-to-succeedpoll-shows.html

Lamas, K. C. A., Freitas, E. R., and Barbosa, A. J. G. (2013). Bullying e Relação Professor-Aluno: Percepções de Estudantes do Ensino Fundamental, Vol. 44. Porto Alegre: Psico.

Lefmann, T., and Combs-Orme, T. (2014). Prenatal stress, poverty, and child outcomes. Child Adolesc. Soc. Work J. 31, 577-590. doi: 10.1007/s10560-014-0340-x

Lindberg, S. M., Hyde, J. S., Petersen, J. L., and Linn, M. C. (2010). New trends in gender and mathematics performance: a meta-analysis. Psychol. Bull. 136, 1123-1135. doi: 10.1037/a0021276

Little, R., and Rubin, D. (2002). Statistical Analysis with Missing Data, 2nd Edn. New York, NY: John Wiley \& Sons, Inc.

Ma, X., and Klinger, D. A. (2000). Hierarchical linear modelling of student and school effects on academic achievement. Can. J. Educ. 25, 41-55. doi: $10.2307 / 1585867$

Martin, M. O., Mullis, I. V., and Foy, P. (2011). Age distribution and reading achievement configurations among fourth-grade students in PIRLS 2006. IERI Monogr. Iss. Methodol. Large Scale Assess. 4, 9-33. Available online at: http://www.ierinstitute.org/fileadmin/Documents/IERI_Monograph/IERI_ Monograph_Volume_04_Chapter_1.pdf

Marzocchi, M., and Oliveira, A. (2009). "Interlocução entre autonomia escolar e desempenho: Quais as analogias possiiveis?", in XIV Congresso Brasileiro de Sociologia. Proceedings (Rio de Janeiro: SBS).

McCoy, L. P. (2005). Effect of demographic and personal variables on achievement in eighth grade algebra. J. Educ. Res. 98, 131-135. doi: 10.3200/JOER.98.3.131-135

Mello, G. N. (1994). "Escolas eficazes: um tema revisitado," in Gestão Escolar: Desafios e Tendências, ed A. C. Xavier, J. A. Sobrinho, and F. Marra (Orgs) (Brasília: Ipea), 329-369.

Menezes-Filho, N. (2007). Os Determinantes do Desempenho Escolar no Brasil. Instituto Futuro Brasil, IBMEC São Paulo e Faculdade de Economia e Administração da Universidade de São Paulo. Executive Summary.

Menezes-Filho, N., Vasconcelos, L., Werlang, S. R. C., and Biondi, R. L. (2009). "Avaliando o Impacto da Progressão Continuada nas Taxas de Rendimento e Desempenho Escolar do Brasil. Certificação ocupacional," in Certificação Para Dirigentes Regionais de Ensino. Available online 
at: http://www.recursoshumanos.sp.gov.br/Arquivos/ProgressaoContinuadaCDRE-001-2009.pdf

Ministério da Educação (2001). SAEB 2001: Novas Perspectivas, 2. Brasília: Ministério da Educação.

Ministério da Educação (2009). Ensino Fundamental De nove Anos: Passo a Passo do Processo de Implantação, Vol. 2. Brasília: Ministério da Educação.

Ministério da Educação (2014). Censo Escolar da Educação Básica 2013. Technical abstract. Instituto Nacional de Estudos e Pesquisas Educacionais Anísio Teixeira, Brasília.

Ministério da Educação (2015). IDEB - Resultados e Metas. Version v1.1.0.0182118187. Update: 03/06/2015. Available online at: http://ideb. inep.gov.br/

Mitchell, D. E., and Collom, E. (2001). The Determinants of Student Achievement at the Academy for Academic Excellence. California, CA: School of Education; University of California.

Moore, K. A., Redd,. Z., Burkhauser,. M., Mbwana,. K., and Collins, A. (2009). "Children in poverty: trends, consequences, and policy options," in Children Trends. Available online at: http://www.childtrends.org/wpcontent/uploads/2013/11/2009-11ChildreninPoverty.pdf

Escardibul, J. O., and Mora, T. (2013). Teacher gender and student performance in mathematics. evidence from California (Spain). J. Educ. Train. Stud. 1. Available online at: http://www.ieb.ub.edu/phocadownload/documentostrabajo/ doc2013-7.pdf

Mortimore, P. (1991). "Effective schools from a british perspective," in Rethinking Effective Schools: Research and Practice, Chapter 7, eds J. Bliss, W. A. Firestone, and C. E. Richards (Englewood Cliffs, NJ: Prentice Hall).

Murillo, F. J. (2007). "School effectiveness research in Latin America," in International Handbook of School Effectiveness and Improvement, ed T. Townsend (New York, NY: Springer), 75-92.

Murillo, F. J., and Martinez-Garrido, C. (2014). Homework and primary-school students' academic achievement in Latin America. Int. Rev. Educ. 60, 661-681. doi: 10.1007/s11159-014-9440-2

Murillo, F. J., and Román, M. (2011). School infrastructure and resources do matter: analysis of the incidence of school resources on the performance of Latin American students. School Effect. School Improv. 22, 29-50. doi: 10.1080/09243453.2010.543538

Napier, D. B. (2014). Qualities of Education in a Globalised World. Rotterdam: Sense Publishers

Neji, H. A., Ukwetang, J. O., and Nja, C. O. (2014). Evaluating the Adequacy of laboratory facilities on students' academic Performance in Secondary School in Calabar, Nigeria. IOSR Journal of Research \& Method in Education (IOSRJRME). 4, 11-14. doi: 10.9790/7388-04331114

Neves, E. R., and Boruchovitch, E. (2004). A Motivação de Alunos no Contexto da Progressão Continuada. Psicologia Teoria Pesquisa 20, 77-85. doi: 10.1590/s0102-37722004000100010

Núñez, J. C., Suárez, N., Rosário, P., Vallejo, G., Cerezo, R., and Valle, A. (2015). Teachers' feedback on homework, homework-related behaviors, and academic achievement. J. Educ. Res. 108, 204-216. doi: 10.1080/00220671.2013. 878298

OECD (2014a). Perspectives on Global Development 2014: Boosting Productivity to Meet the Middle-Income Challenge, Paris: OECD Publishing.

OECD (2014b), Education at Glance 2014 - Brazil. Paris: OECD Publishing. Available online at: https://www.oecd.org/brazil/EAG2014-Country-NoteBrazil.pdf

Paget, C., Malmberg, L., and Martelli, D. (2016). Brazilian national assessment data and educational policy: an empirical illustration. Assess. Educ. Principles Policy Pract. 23, 98-125. doi: 10.1080/0969594x.2015.1113929

Palermo, G. A. (2011). Fatores Associados ao Desempenho Escolar: Uma Análise da Proficiência em Matemática dos Alunos do $5^{\circ}$ ano do Ensino Fundamental da rede Municipal do Rio de Janeiro. Master's thesis, Escola Nacional de Ciências Estatísticas.

Parelius, R., and Parelius, A. (1987). Sociology and the Field of Education. Prentice Hall.

Passador, M. M., Lima, P. R., De Pieri, C., Harakava, R., and Furtado, E. L. (2012). Teratosphaeria nubilosa em plantações comerciais de Eucalyptus globulus nas regiões Sul e Sudeste do Brasil. Summa Phytopathol. 38, 11-16. doi: 10.1590/S0100-54052012000100002
Peng, S. S., and Hall, S. T. (1995). Understanding Racial-Ethnic Differences in Secondary School Science and Mathematics Achievement. NCES No. 95710, Washington, DC: Department of Education.

PISA (2012). Results in Focus: What 15-Year-Olds Know and What They Can do with What They Know. Available online at: http://www.oecd.org/pisa/ keyfindings/pisa-2012-results-overview.pdf

Riani, J. D. L. R., and Rios-Neto, E. L. G. (2008). Background familiar versus perfil escolar do município: qual possui maior impacto no resultado educacional dos alunos brasileiros? Rev. Brasil. Estud. População. 25, 251-259. doi: 10.1590/S0102-30982008000200004

Sammons, P. (1995). Key Characteristics of Effective Schools: A Review of School Effectiveness Research. Ringwood: B and MBC Distribution Services.

Sayed, Y., and Kanjee, A. (2013). Assessment in Sub-Saharan Africa: challenges and prospects. Assess. Educa. Principles Policy Practice 20, 373-384. doi: 10.1080/0969594X.2013.849056

Scheerens, J. (2000). School Effectiveness in Developed and Developing Countries. Available online at: http://www.worldbank.org/en/topic/education

Scheerens, J. (2001). Monitoring school effectiveness in developing countries. School Effect. School Improv. 12, 359-384. doi: 10.1076/sesi.12.4.359.3447

Segretin, S. M., Lipina S. J., and Petetta, D. R. (2009). Consideraciones metodológicas y conceptuales para el análisis de predicción del desempeño escolar en base a indicadores de contexto hogareño y escolar. Rev. Iberoamericana Eval. Educ. 2, 105-123. Available online at: http://www.rinace. net/riee/numeros/vol2-num2/art6_htm.html

Silva, R., Davis, C., Esposito, Y., and Mello, G. (1993). O Descompromisso das políticas públicas com a qualidade do ensino. Caderno Pesquisa São Paulo 84, 5-16.

Skaalvik, E. M., and Skaalvik, S. (2011). Teacher job satisfaction and motivation to leave the teaching profession: relations with school context, feeling of belonging, and emotional exhaustion. Teach. Teach. Educ. 27, 1029-1038. doi: $10.1016 /$ j.tate.2011.04.001

Soares, J. F. (2004). O efeito da escola no desempenho cognitivo de seus alunos. Rev. Electrón. Iberoamerica Sobre Calidad, Eficacia y Cambio em Educ. 2. Available online at: http://www.redalyc.org/pdf/551/55120207.pdf

Soares, J. F. (2007). Melhoria do desempenho cognitivo dos alunos do ensino fundamental. Cadernos Pesquisa. 37, 135-160. doi: 10.1590/ s0100-15742007000100007

Soares, J. F., and Alves, M. T. G. (2003). Desigualdades raciais no sistema brasileiro de educação básica. Educação Pesquisa 291, 147-165. doi: 10.1590/S1517-97022003000100011

Soares, J. F., Ribeiro, L. M., Castro, C. D. M. (2001). Valor agregado de instituições de ensino superior em Minas Gerais para os cursos de direito, administração e engenharia civil. Instituto Universitário de Pesquisas do Rio de Janeiro. 44, 363-396. doi: 10.1590/s0011-52582001000200005

Souza, A., and Valle Silva, N. (1994). Origem familiar, Qualidade da Educação e Escolas Públicas e Particulares em São Paulo: Relações e efeitos nas transições Escolares [Family Origins, Quality of Education in Public and Private Schools in Sao Paulo: relationships and Effects in Educational]. Pesquisas e Planejamento Econômico 24, 94-114.

Sundre, D., and Wise, S. L. (2003). "Motivation filtering: an exploration of the impact of low examinee motivation on the psychometric quality of tests," in National Council on Measurement in Education (Chicago, IL).

Sung, Y. T., Shih, P. C., Chang, K. E. (2015). The effects of 3D-representation instruction on composite-solid surface-area learning for elementary school students. Instruct. Sci. 43, 115-145. doi: 10.1007/s11251-014-9331-8

Teddlie, C. (1994). "The study of context in school effects research: history, methods, results and theoretical implications," in Advances in School Effectiveness Research and Practice, eds D. Reynolds, B. P. M. Creemers, P. S. Nesselrodt, E. C. Schaffer, S. Stringfield, and C. Teddlie (Oxford: Pergamon), 85-110.

Teddlie, C., and Reynolds, D. (2000). The International Handbook of School Effectiveness Research. Psychology Press.

Teddlie, C., Stringfield, S., and Reynolds, D. (2000). "Context issues within school effectiveness research," in The International Handbook on School Effectiveness Research, eds C. Teddlie and D. Reynolds (London: Falmer Press), 160-185.

United Nations Educational Scientific and Cultural Organization-UNESCO (2007). EFA Global Monitoring Report 2008. Education for All by 2015 - will we 
make it? Oxford University Press. Available online at: http://unesdoc.unesco. org/images/0015/001547/154743e.pdf

UNICEF (2014). O Enfrentamento da Exclusão Escolar no Brasil. Brasília, DF: UNICEF, Campanha Nacional pelo Direito à Educação.

van Batenburg, T. A., and Laros, J. A. (2002). Graphical analysis of test items. Educ. Res. Eval. 8, 319-333. doi: 10.1076/edre.8.3.319.3856

Velez, E., Schiefelbein, E., and Valenzuela, J. (1994). Factores que afectan el rendimiento academico en la educacion primaria. Revision de la literatura de America Latina y el Caribe [Factors affecting the academic performance in primary education. Review of the literature from Latin America and the Caribbean]. Rev. Latinoamericana Innovac. Educ. 17, 29-53.

Voyer, D., and Voyer, S. D. (2014). Gender differences in scholastic achievement: a meta-analysis. Psychol. Bull. 140, 1174-1204. doi: 10.1037/a0036620

Wiliam, D. (2008). International comparisons and sensitivity to instruction. Assess. Educ. Principles Policy Pract. 15, 253-257. doi: 10.1080/09695940802417426
Wise, S. L., and DeMars, C. E. (2005). Low examinee effort in low-stakes assessment: problems and potential solutions. Educ. Assess. 10, 1-17. doi: 10.1207/s15326977ea1001_1

Conflict of Interest Statement: The authors declare that the research was conducted in the absence of any commercial or financial relationships that could be construed as a potential conflict of interest.

Copyright $\odot 2016$ Menezes, Duran, Mendonça Filho, Veloso, Sarmento, Paget and Ruggeri. This is an open-access article distributed under the terms of the Creative Commons Attribution License (CC BY). The use, distribution or reproduction in other forums is permitted, provided the original author(s) or licensor are credited and that the original publication in this journal is cited, in accordance with accepted academic practice. No use, distribution or reproduction is permitted which does not comply with these terms. 